\title{
Functional Roles of Glycoconjugates in Signal Transduction via Lipid Rafts
}

\author{
脂質ラフトを介するシグナル伝達における複合糖質の機能的役割
}

\author{
Kasahara, Kohji ; and Sanai, Yutaka \\ The Tokyo Metropolitan Institute of Medical Science, Tokyo Metropolitan Organization for Medical Research, Bunkyo-ku, \\ Tokyo 113-8613, Japan, FAX : 81-3-3828-6663, E-mail : kasahara@ rinshoken.or.jp
}

Key Words : carbohydrate, glycoconjugate, glycosphingolipid, GPI-anchored protein, lipid raft

\begin{abstract}
Glycosphingolipid-cholesterol formed as microdomains in cell membranes have been proposed to function as rafts for the attachment of specific proteins including glycosylphosphatidylinositol-anchored proteins, glycoproteins and proteoglycans. The microdomains are postulated to be involved in transmembrane signaling. Here, the functional roles of glycoconjugates in the physical properties of these microdomains, as well as in signal transduction are discussed.
\end{abstract}

要 約

スフィンゴ糖脂質とコレステロールは生体膜においてミク ロドメインを形成し、グリコシルホスファチジルイノシトール アンカータンパク質、糖タンパク質、プロテオグリカンを含む 特異的なタンパク質が付着するラフト（いかた）として働いて いることが提唱されている。そのミクロドメインは膜を介する シグナル伝達に関与していると考えられている。ここではミク ロドメインの物理的性質、シグナル伝達における複合糖質の機 能的役割について論じる。

\section{A. Introduction}

Recent studies suggest that glycosphingolipids (GSLs) exist in clusters and form microdomains containing cholesterol in cell membrane. The GSL- and cholesterol-rich microdomains are referred to as lipid rafts or caveolae membrane (1-5). Lipid rafts are implicated in signal transduction, because signaling molecules such as the src-family kinases and trimeric G proteins, are associated with them via lipid modification. Low-density, detergent-insoluble membrane fractions can be isolated from cells by density gradient centrifugation, which are rich in sphingolipids (GSLs, sphingomyelin), cholesterol, glycosylphosphatidylinositol (GPI)-anchored proteins, and a variety of signaling molecules. These observations indicate the possible presence of lipid rafts in cells. These membrane fractions are referred to as detergent-resistant membranes (DRM) (6), which appear to be present in all mammals, sea urchin (7, 8), Drosophila melanogaster, (9) Caenorhabditis elegans, (10) Saccharomyces cerevisiae, (11) Dictyostelium (12) and protozoan parasites such as Trypanosoma brucei, (13)Tetrahymena mimbres. (14). The presence of lipid rafts in vivo is supported by several lines of evidence, including the results of a singleparticle tracking study, a fluorescence resonance energy transfer study, a photonic force microscopic study and a chemical crosslinking study (1).

The basic forces driving the formation of rafts are thought to be lipid interactions, which are weak and transient (6). Sphingolipids are relatively rich in saturated fatty acyl chains, which allow tight packing and confer the characteristic of a high melting temperature. On the other hand, phospholipids are relatively rich in cis-unsaturated fatty acyl chains (kinked struc-

\section{A. 序 論}

最近の研究から、スフィンゴ糖脂質（GSL）は生体膜にお いてコレステロールとともに集合しミクロドメインを形成して いることが示唆されている。そのスフィンゴ糖脂質とコレステ ロールに富むミクロドメインは、脂質ラフトまたはカべオラ膜 と呼ばれている (1-5)。脂質ラフトはsrcファミリーキナーゼや三 量体 $\mathrm{G}$ タンパク質が脂質修飾を介して会合していることからシ グナル伝達に関係していると考えられている。スフィンゴ脂質 （GSLとスフィンゴミエリン）、コレステロール、GPIアンカー タンパク質やさまざまなシグナル伝達分子に富む低密度界面活 性剂不溶性膜画分が、密度勾配遠心により細胞から単離するこ とができる。これは、細胞に脂質ラフトが存在する可能性を示 している。これら膜画分はdetergent-resistant membranes (DRM) と 呼ばれ(6)、すべての哺乳類、ウニ(7、8)、八工(9)、線虫(10)、酵 母(11)、細胞性粘菌(12)、トリパハソーマ(13)やテトラヒメナ(14) などの原生生物に存在していることが明らかになっている。生 体内において脂質ラフトが存在することは、一分子追跡、蛍光 共鳴エネルギー移動、原子間力顕微鏡、化学架橋などの研究か ら得られたいくつかの証拠により支持されている(1)。

ラフトの形成に働く基本的な力は、脂質相互作用であり弱 く一時的なものであると考えられている。スフィンゴ脂質は相 対的に飽和脂肪酸鎖に富み、固くパックすることができ相転移 温度が高い性質を持つ。一方、リン脂質は相対的にシス二重結 合不飽和脂肪酸鎖（よじれ構造）に富み、固くパックすること ができず相転移温度が低い性質を持つ。そしてスフィンゴ脂質 
ture), which prevents tight packing and confers the characteristic of a low melting temperature. Sphingolipids and cholesterol are thought to exist as phase-separated domains from phospholipids in the membrane. The lipid composition renders the rafts and their constituent proteins resistant to solubilization with non-ionic detergents such as Triton X-100.

A number of studies have examined the influence of cholesterol on the physical properties and signaling of lipid rafts. Cholesterol depletion by treatment with cyclodextrin results in disruption of lipid rafts and perturbation of raft-mediated signaling.

\section{B. Glycoconjugate Functions in Physical Properties of Lipid Rafts}

In mammalian cells, there are two major classes of sphingolipids: GSLs and sphingomyelin (SM), both of which are synthesized from the hydrophobic molecule ceramide. GSLs and SM have different polar head groups, carbohydrate-chain and phosphocholine, respectively.

Deprivation of sphingolipids leads to increased solubility of GPI-anchored proteins with Triton X-100 using CHO temperature-sensitive mutant defective in serine palmitoyltransferase activity for sphingolipid synthesis (15). DRM are reduced by treatment of cells with fumonisin, which inhibits ceramide synthase and blocks both GSL and SM biosynthesis (16-18). These observations suggest that sphingolipids are important for the formation of lipid rafts.

PDMP is an inhibitor of ceramide glycosyltransferase (GlcCer synthase), which blocks a first step of most GSL biosynthesis, but not SM biosynthesis (19). Single-particle tracking of a GPI-anchored protein and GSLs in intact cell membrane showed transient confinement in patches, which are thought to represent lipid rafts in vivo. The size of the confining domain for the GPI-anchored protein is reduced by treatment with PDMP (20). GSL depletion by PDMP causes elimination of src from the lipid raft fraction on a density gradient (21).

DRM are not detected in the presence of octylglucoside. This is attributed to the resemblance of the detergent to GSLs. Incubation of cells with lyso-GSL reduces GSL clustering (22). Furthermore, exogenously administered gangliosides abolished clustering of the GPI-anchored protein in lipid rafts and increased their detergent solubility (23). These observations suggest that GSLs are also important for the formation of lipid rafts.

GSL self-association through hydrogen bonds between the GSL headgroups is thought to contribute to the formation of lipid rafts (5). (i) GSLs have much higher melting temperature than SM (6). (ii) GlcCer synthase-deficient tumor cell mutant does not express GSLs, and up-regulated expression of SM compensates for the lack of GSLs. However, the yield of DRM protein is 2-fold higher in the parental than the mutant line (24). (iii) Furthermore, enzymatic removal of the carbohydrate moi-
とコレステロールは膜においてリン脂質から相分離した領域と して存在すると考えられている。その脂質構成から、ラフトお よびラフト構成タンパク質はトリトンX-100のような非イオン性 界面活性剂に対し不溶性となる(6)。

脂質ラフトの物理的性質、シグナル伝達におけるコレステ ロールの影響についての研究は数多くある。たとえばシクロデ キストリン処理によりコレステロールを除去すると、脂質ラフ トは壤れラフトを介するシグナル伝達は擋乱される。

\section{B．脂質ラフトの物理的性質における複合糖質の役割}

哺乳動物細胞のスフィンゴ脂質には、GSLとスフィンゴミ エリン(SM)の主に二つのクラスがあり両方とも疎水性分子であ るセラミドから合成される。GSLsとSMとは異なる極性頭部を 持ち、それぞれ糖鎖とホスホコリンである。スフィンゴ脂質を 合成するセリンパルミトイルトランスフェラーゼ温度感受性変 異CHO細胞において、スフィンゴ脂質が欠損すると結果的に GPIアンカータンパク質のトリトンX-100に対する溶解性が増す (15)。七ラミド合成を阻害LGSLとSMの両方の生合成を止める フモニシンで細胞を処理するとDRMが減る(16-18)。これらは、 脂質ラフトの形成にスフィンゴ脂質が重要であることを示して いる。

PDMPはセラミドグルコース転移酵素（グルコシルセラミド 合成酵素) の阻害剤で、ほとんどのGSLの生合成の最初の反応 を止めるがSMの生合成過程には影響を及ぼさない(19)。無傷細 胞膜上においてGPIアンカータンパク質およびGSLの一分子軌跡 は瞬間的のある一区画に局在化するが、それは脂質ラフトを表 わしているものであると考えられている。PDMP処理により、 そのGPIアンカータンパク質の局在化する領域の大きさが小さく なる(20)。PDMPによりGSLを欠損させると、密度勾配遠心にお いて srcはラフト画分から排除される(21)。

オクチルグルコシド存在下ではDRMは検出されないが、こ の界面活性剤がGSLと構造が似ていることによる。またりゾ体 GSLを細胞とインキュベーションするとGSLクラスターが減少 する(22)。さらに外からガングリオシドを加えるとGPIアンカー タンパク質の脂質ラフトでのクラスター化が減少し、界面活性 剂に対する溶解度が増加する(23)。これらのことはGSLsもまた 脂質ラフトの形成に重要であることを示している。

GSL頭部間の水素結合によるGSL自己会合は、脂質ラフト の形成に寄与していると考えられている(5)。たとえば（i） GSLsはSMよりも高い相転移温度を持つ(6)。（ii）グルコシルセ ラミド合成酵素欠損癌細胞変異体はGSLsを発現していないが、 SMの発現増加がその分を補っている。しかし親細胞における DRM構成タンパク質の量は変異細胞の二倍である(24)。（iii） 


\section{A : Trans-interaction}
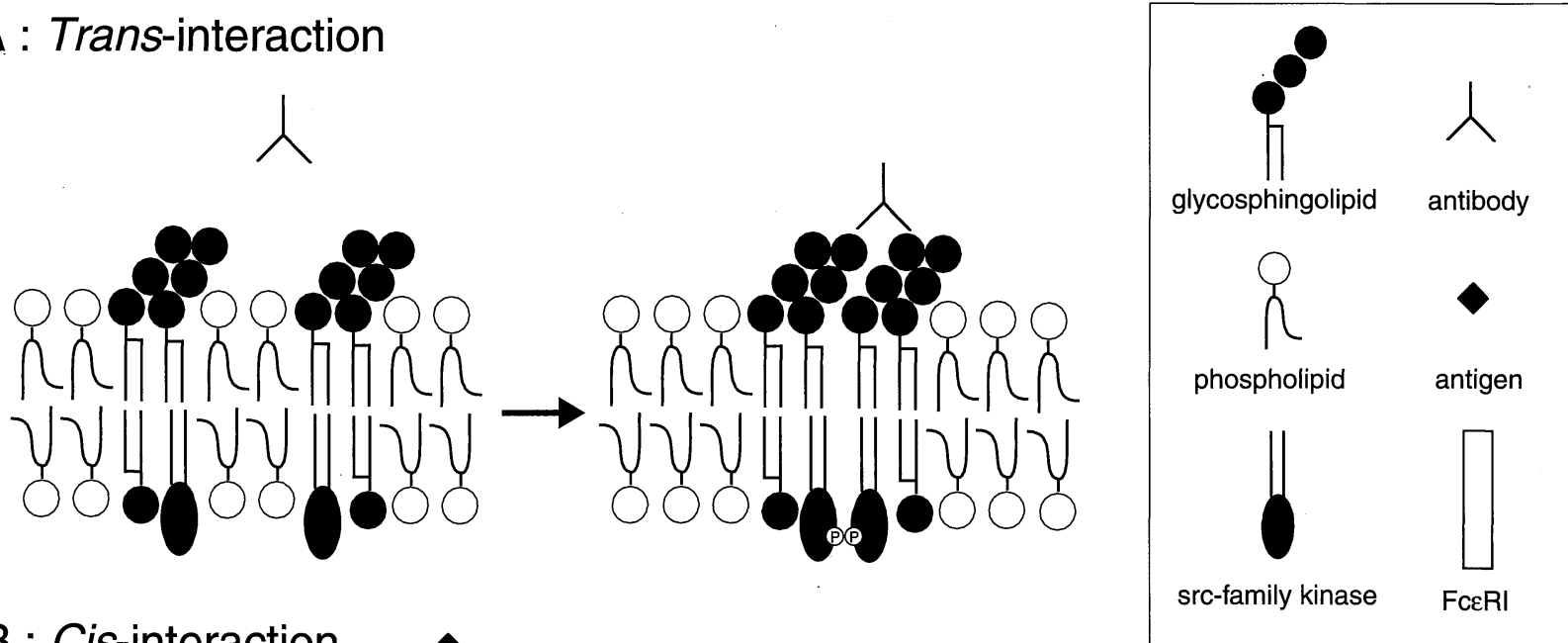

B : Cis-interaction

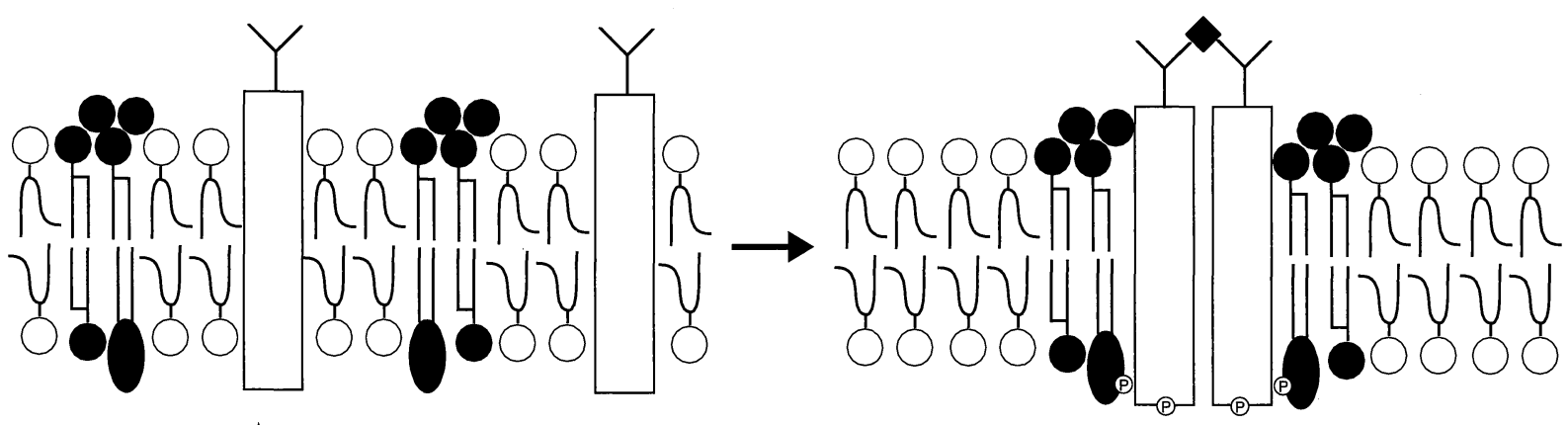

Fig.1 Two modes of interaction with lipid raft. (A) Trans-interaction : GSL ligation induces coalescence of lipid rafts (28). (B) Cis-interaction : Receptor ligation induces translocation to lipid rafts or stabilization of raft-association. For example, (i) aggregation of IgE-FceRI by antigen induces coalescence of FceRI with lipid rafts (36), (ii) antibody-mediated crosslinking GPI-anchored protein increases the amount of GPI-anchored protein in the lipid raft fraction on a density gradient (79), (iii) NGF treatment increases association of Trk with ganglioside GM1 (41).

ety from cell-surface GSLs induces an alteration of GPI-anchored protein distribution on a density gradient (25). These observations suggest that the carbohydrate-chain of GSLs can affect the physical properties of lipid rafts.

\section{Glycoconjugate Functions in Signal Transduction via Lipid Rafts}

There are two modes of interaction of molecules with lipid rafts (Fig.1) ; (A) interaction of exogenous molecules such as diffusible factor, extracellular matrix, or membrane molecule of the other cell (trans-interaction), e.g. association of anti-GSL antibody with carbohydrate-chain of GSLs (B) interaction of membrane-associated molecule within the same cell membrane, such as GPI-anchored protein, immunoreceptor and growth factor receptor. (cis-interaction).

\section{C-1. GSL signaling (26-28)}

Association of antibody and toxin with cell-surface GSLs has been shown to induce activation of src-family kinases in
さらに細胞表面のGSL糖鎖を酵素で除去すると密度勾配遠心に おけるGPIアンカータンパク質の分布が変化する(25)。

これらのことはGSL糖鎖は脂質ラフトの物理的性質に影響を 与えることができることを示している。

C. 脂質ラフトを介するシグナル伝達における複合糖質の役割 脂質ラフトと分子の相互作用には二つの様式がある（図 1）。（A）拡散性因子、細胞外マトリックス、他の細胞表面 上の膜分子などの外来性分子との相互作用（トランス相互作 用、例：抗GSL抗体とGSL糖鎖との相互作用）と、（B）GPIP ンカータンパク質、免疫受容体、増殖因子受容体など同じ細胞 膜内での膜会合分子との相互作用（シス相互作用）である。

\section{C-1. GSLシグナリング(26-28)}

細胞表面のGSLsと抗体または毒素との会合が脂質ラフトに おいて srcファミリーキナーゼを活性化することが示されてきた が、これはGSL糖鎖とそのリガンドとの相互作用による膜を介 
lipid rafts, suggesting the presence of transmembrane signaling through interaction of GSL carbohydrates with their ligands in vivo. One possible ligand is GSL on adjacent cell surface. Hakomori et al. has demonstrated cell adhesion and signal transduction through carbohydrate-carbohydrate interaction in B16 melanoma (29). The cell adhesion and signal transduction are inhibited by preincubation with anti-GSL antibody, or lyso GSL (30). Carbohydrate-carbohydrate interaction is also shown using GSL monolayers by surface plasmon resonance (31).

Lectins have been reported as natural ligands for GSLs, such as selectin, galectin, sialoadhesin and myelin-associated glycoprotein $(28,29)$. Affinity of sialoadhesin on the cell surface for GSL polymer is higher than that for GSL monomer (32). In GSL/phospholipid mixed monolayers, affinity of lectin for phase-separated GSL is higher than that for homogeneouly mixed GSL (33). These observations suggest that cell-cell contact via lectin-GSL interaction may induce signal transduction in lipid rafts. However, the physiological significance remains to be explored.

\section{C-2. GPI-Anchored Protein Signaling}

GPI-anchored proteins have been implicated in transmembrane signaling via lipid rafts. GPI-anchored protein signaling and GSL signaling share many properties $(27,28)$. (i) Anti-GPI-anchored protein antibody, as well as anti-GSL antibody, co-precipitate src-family kinases. (ii) Antibody-mediated crosslinking of GPI-anchored proteins as well as GSLs induces activation of src-family kinases; (iii) both induce transient tyrosine phosphorylation of common downstream molecules; (iv) both induce $\mathrm{Ca}^{2+}$ flux. Thus, GPI-anchored protein and GSLs transduce signals using the same pathway. Enzymatic removal of the carbohydrate moiety from cell-surface GSLs impairs activation of the src-family kinase by antibody-mediated crosslinking of GPI-anchored protein (25). This observation suggests that GSLs are involved in GPI-anchored protein signaling.

The association of GPI-anchored proteins with lipid rafts is developmentally regulated during oligodendrocyte maturation (34). In oligodendrocyte progenitor cells which do not synthesize galactocerebroside (GalCer), a major GSL in myelin, the GPI-anchored neuronal cell adhesion molecule, F3, is not present in lipid rafts and is not associated with the src-family kinase Fyn. In contrast, F3 from maturing oligodendrocytes and from myelin is present in lipid rafts and is associated with Fyn.

\section{C-3. Immunoreceptor Signaling}

Lipid rafts are involved in signaling by immunoreceptors, such as the T-cell antigen receptor (TCR) and IgE receptor (FceRI) $(35,36)$. Efficient T-cell activation requires one signal from a TCR and a second signal from the costimulatory molecule. The costimulation leads to the recruitment of lipid rafts to the site of cell-cell contact between the $\mathrm{T}$ cell and antigen-
するシグナル伝達が生体内においても存在していることを示唆 している。可能性のある一つのリガンドは隣の細胞上のGSLであ る。箱守らはB16メラノーマにおけるGSLsの糖鎖-糖鎖相互作用 が細胞接着およびシグナル伝達をおこすことを報告している (29)。その細胞接着およびシグナル伝達は、あらかじめ抗GSL抗 体またはリゾ体GSLでインキュベーションすることで阻害される (30)。糖鎖-糖鎖相互作用は、GSL単分子層を用いた表面プラズモ ン共鳴法によっても示されている(31)。

GSLsの生理的リガンドとしてセレクチン、ガレクチン、シ アロアドヘシン、ミエリン会合糖タンパク質などのレクチンが 報告されている(28,29)。細胞表面のシアロアドヘシンとGSLポリ マーとの親和力はGSLモノマーとの親和性より強い(32)。また GSLとリン脂質の混合単分子層において、レクチンとGSLの親和 力は、GSLが均一に混ざっている時より相分離をおこしている時 のほうが強い(33)。これらのことは、レクチン-GSL相互作用によ る細胞間接着が脂質ラフトでおきる可能性を示している。しか し、その生理的意義についてはまだ研究が進んでいない。

C-2. GPIアンカータンパク質シグナリング

GPIアンカータンパク質は脂質ラフトにおける膜を介するシ グナル伝達に関係していると考えられてきた。GPIアンカータン パク質シグナリングとGSLシグナリングとでは多くの性質が共通 している $(27,28)$ 。(i)抗GPIアンカータンパク質抗体は抗GSL抗体 と同様にsrcファミリーキナーゼを共沈する。(ii)抗体でGPIアン カータンパク質をクロスリンクすると、GSLをクロスリンクした 時と同様にsrcファミリーキナーゼが活性化し(iii)共通のシグナル 伝達下流分子の一過性のチロシンリン酸化がおこり(iv)カルシウ ム流入が抗こる。このようにGPIアンカータンパク質とGSLsは同 じ経路でシグナルを伝達している。細胞表面のGSL糖鎖を酵素で 除去するとGPIアンカータンパク質クロスリンクによるsrcファミ リーキナーゼの活性化がおこらなくなる(25)。これはGPIアン カータンパク質シグナリングにGSLが関与していることを示して いる。

GPIアンカータンパク質と脂質ラフトの会合は、オリゴデン ドロサイトが成熟する際、発生にともない制御されている(34)。 ミエリンにおける主要なGSLであるガラクトシルセラミドは、オ リゴデンドロサイト前駆細胞においては合成されておらず、こ のときGPIアンカー神経細胞接着分子F 3 は脂質ラフトに存在せ ずsrcファミリーキナーゼFynとは会合してない。これに対し、成 熟オリゴデンドロサイトやミエリンにおいてはF 3 はラフトに存 在しFynと会合している。

\section{C-3. 免疫受容体シグナリング}

脂質ラフトはT細胞抗原受容体（TCR） PIgE受容体(Fc $\varepsilon$ RI) のシグナル伝達に関与している(35,36)。T細胞を充分に活性化す るにはTCRによる第一のシグナルの他に、共刺激分子からの第 二のシグナルも必要である。共刺激によりT細胞と抗原提示細胞 との細胞間接着部位に脂質ラフトが集合する。 $\mathrm{src}$ ファミリーキ ナーゼ、LAT、シグナル伝達下流分子を脂質ラフトに集め、さ 
Trends in Glycoscience and Glycotechnology Vol.13 No.71 (May 2001) pp.251-259

presenting cell. The concentration of src-family kinases, LAT and downstream molecules, and exclusion of tyrosine phosphatase CD45 allow strong and sustained tyrosine phosphorylation of several substrates (37). Aggregation of IgE-FceRI by antigen also induces coalescence of FceRI with lipid rafts, activation of the src-family kinases and histamine release from mast cells (36).

One of the RBL-2H3 variants, that was initially selected for deficiency in FceRI-mediated histamine release, was found to lack expression of the ganglioside. Antigen stimulation did not induce PI turnover, activation of phospholipase A2, C and $\mathrm{D}, \mathrm{Ca}^{2+}$ flux and histamine release in the variant, even though it expresses FceRI (38). Interestingly, deficiency of ganglioside expression and antigen-stimulated signaling is restored by transfection of active Rho family Cdc 42 .

\section{C-4. Growth Factor Receptor Signaling}

GSLs have been shown to be modulators of growth factor receptor signaling (29). However, the underlying molecular mechanism remains to be explored. Recent papers show a modulation mechanism in lipid rafts. In rat pheochromocytoma PC12 cells, NGF triggers neuronal differentiation, but EGF elicits a proliferation, although downstream molecules of signal transduction are virtually identical. NGF induces sustained ERK activation, whereas EGF induces transient activation. Duration of ERK activation is critical for neuronal differentiation. However, the mechanism of different time response remains to be clarified (39). A recent paper shows that Trk of PC 12 cells is present in lipid raft fraction. Furthermore, removal of cholesterol by cyclodextrin inhibits NGF-induced, but not EGF-induced, ERK activation (40). Therefore, NGF-induced sustained activation might be due to the presence of Trk in lipid rafts. Consistent with this idea, exogenous ganglioside GM1 increases NGF-induced autophosphorylation of Trk, but not EGF-receptor autophosphorylation in PC12 cells (41). GSL depletion by PDMP inhibits NGF-induced autophosphorylation of Trk and neurite outgrowth, but not EGF-mediated signaling, in PC12 cells (42). Transfection of the ganglioside GD3 synthase cDNA induced dimerization and activation of Trk and MAP kinase without NGF treatment in PC12 cells (43). Furthermore, unglycosylated Trk can hardly respond to NGF, which does not associate with lipid rafts (44). Glycosylation may affect interaction of membrane proteins with lipid rafts.

Exogenous ganglioside GM3 inhibits EGF-induced autophosphorylation of the EGF receptor and proliferation of A431 epidermoid carcinoma cells (45). Depletion of ganglioside GM3 by sialidase gene transfection or treatment with PDMP appeared to increase EGF receptor autophosphorylation and proliferation of A431 cells $(46,47)$. A recent paper showed that EGF receptor of A431 cells is present in lipid raft fraction (48). Thus, EGF receptor is also regulated in lipid rafts. The precise cis-regulation mechanism of membrane proteins with GSLs re-
らにチロシンホスファターゼCD45を排除することで、基質の強 く持続するチロシンリン酸化を可能にしT細胞を充分に活性化す る(37)。マスト細胞においても抗原によるIgE-Fc $\varepsilon$ RIの凝集が脂 質ラフトとFc $\varepsilon \mathrm{RI}$ 会合を引き起こし、 $\mathrm{src}$ ファミリーキナーゼ を活性化しヒスタミンの放出をおこす。

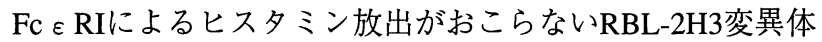
の中に、GSLsを発現していないものがある。その変異体ではFc $\varepsilon \mathrm{RI}$ 発現しているにもかかわらず、抗原刺激によるPI夕ーン オーバー、ホスホリパーゼA 2，C，Dの活性化、カルシウム 流入がおこらない(38)。面白いことに、この細胞に活性化型Rho ファミリーCdc42をトランスフェクションすると、GSLsの発現 と抗原刺激によるシグナル伝達レベルがもとにもどる。

\section{C-4. 増殖因子受容体シグナリング}

GSLsは増殖因子受容体シグナリングの調節因子であること が示されてきた(29)。しかしその分子機構については、はっきり していない。最近の論文は脂質ラフトによる調節機構を示して いる。ラット褐色細胞腫PC12において、NGFは神経分化を引き 起こしEGFは細胞増殖をひきおこすが、シグナル伝達下流分子 は実質上同じである。NGFは持続的なERK活性化をおこすが、 EGFは一過性のERK活性化をおこす。神経分化には持続的な ERK活性化が重要であると考えられている。しかし時間的に異 なる反応をおこす機構は明らかになっていない(39)。最近の論文 は、PC12細胞においてTrkが脂質ラフト画分に存在することを示 している。さらにシクロデキストリンによるコレステロール除 去で、NGFによる ERK活性化は阻害されるが、EGFによる ERK 活性化は阻害されないことがわかった(40)。よってNGFによる持 続的な活性化は、Trkが脂質ラフトに存在することによる可能性 がある。この考えと一致することに、ガングリオシドGM 1 添加 はNGFによるTrkの自己リン酸化は促進するがEGFによるEGF受 容体の自己リン酸化は促進しない(41)。PDMPによりGSLを欠損 させると、PC12細胞においてNGFによるTrkの自己リン酸化と神 経突起伸長は阻害されるが、EGFによるシグナル伝達は阻害さ れない(42)。ほかの例としてPC12細胞にガングリオシドGD 3 合 成酵素cDNAをトランスフェクションすると、NGFなしでTrkの 二量体化と活性化がおこる(43)。さらに、糖鎖修飾されてない Trkは脂質ラフトとは会合せず、NGFにほとんど反応しないこと がわかっている(44)。糖鎖修飾が膜タンパク質と脂質ラフトの会 合に影響するのかもしれない。

偏平上皮癌細胞A431においてガングリオシドGM 3 添加は EGFによるEGF受容体の自己リン酸化と細胞増殖を阻害する (45)。シアリダーゼ遺伝子トランスフェクションまたはPDMP処 理によりガングリオシドGM 3 を欠損させるとEGFによるEGF受

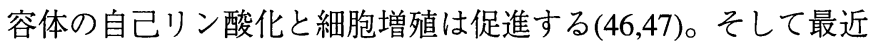
A431細胞においてEGF受容体は脂質ラフト画分に存在すること が報告された(48)。GSLsによる膜タンパク質の正確なcis調節機 構は、まだはっきりしていない。cis調節の一つの機構として形 質膜におけるGSLと膜タンパク質の直接相互作用がある(49- 
mains obscure. One of the mechanisms is direct-interaction of membrane proteins with GSLs on plasma membrane (49-51).

\section{C-5. Proteoglycan Signaling}

Type IIA secretory phospholipase A2 (sPLA2-IIA) is associated with glypican, a GPI-anchored heparan sulfate proteoglycan, on the cell surface caveolae, and transferred to subcellular compartments. Then, sPLA2-IIA is thought to catalyzes release of arachidonic acid in the perinuclear compartment of rat $3 Y 1$ fibroblasts (52).

Phosphacan, a neural tissue-specific chondroitin sulfate proteoglycan, is a high-affinity ligand of TAG-1, a GPI-anchored neuronal cell adhesion molecule.

The binding is decreased by treatment of phosphacan with chondroitinase (53). Phosphacan induces activation of src-family kinase and protein tyrosine phosphorylation in lipid rafts of rat cerebellar primary cultures (25).

\section{C-6. Involvement of Lectin}

Galectin-1 is an endogenous lectin with known T cell immunoregulatory activity. Galectin-1 induces partial TCR signaling via lipid rafts (54). This is probably due to clustering lipid rafts, because cyclodextrin-mediated raft disruption inhibits the signaling. Furthermore, galectin- 1 antagonizes antigen-induced signal transduction and TCR/costimulator dependent lipid raft clustering at the TCR contact site. Galectin- 1 associates with ganglioside GM1 (55) or glycoprotein in lipid rafts. However, galectin- 1 counter ligands remain to be elucidated.

Several papers report lectin-like molecules associated with lipid rafts: VIP36 $(56,57)$, annexin II,V,VI (58-62), ZG16p (18). However, the functional role of these lectins in raft-mediated signaling remains to be explored.

\section{Heterogeneity in Lipid Rafts}

Compositional, distributional and functional heterogeneity is known to exist among lipid rafts. Detergent-insoluble membrane is separated into two distinct subfractions visible as discrete light-scattering bands by density gradient centrifugation. There was a clear difference in their GSL compositions. Both bands are enriched in SM, cholesterol, GPI-anchored proteins. However, GalCer, annexin II and VI are only enriched in the higher-density fraction of porcine lung membranes (63). GSLs are enriched in the higher-density fraction of mouse cerebellum (64). In melanoma, two membrane subfractions were separated from the low-density, detergent-insoluble fractions by immunoprecipitation. The GM3-rich fraction, separated using the antiGM3 antibody, contained sphingomyelin, cholesterol and c-src, but not caveolin. In contrast, the caveolin-containing fraction, separated using the anti-caveolin antibody, contained GlcCer, a large quantity of cholesterol and Ras (65).

In dorsal root ganglionic neurons also, two subfractions were separated by immunoisolation. The GPI-anchored prion protein, located primarily in the cell body, was relatively soluble
$51)$ 。

\section{C-5. プロテオグリカンシグナリング}

ラット線維芽細胞3Y1においてタイプIIA分泌型ホスホリ パーゼA2は、細胞表面のカベオラに存在するGPIアンカーへパ ラン硫酸プロテオグリカンであるグリピカンに結合し細胞内コ ンパートメントに輸送される。そして核周辺のコンパートメン トでのアラキドン酸産生を触媒すると考えられている(52)。

神経組織特異的コンドロイチン硫酸プロテオグリカンであ るフォスファカンは、GPIアンカー神経細胞接着分子TAG-1の高 親和性リガンドである。フォスファカンをコンドロイチナーゼ で処理すると、その会合は減少する(53)。フォスファカンは ラット小脳初代培養細胞の脂質ラフトにおいて、 srcファミリー キナーゼを活性化しチロシンリン酸化を引き起こす $(25)$ 。

\section{C-6.レクチンの関与}

ガレクチンー1はT細胞の免疫調節活性を持つことが知られ る内在性レクチンである。ガレクチンー 1 は脂質ラフトを介し て部分的にTCRのチロシンリン酸化を引き起こす(54)。シクロ デキストリンによるラフトの破壊でそのシグナルが阻害される ことから、これはおそらく脂質ラフトのクラスター化によって いる。さらにガレクチンー 1 は抗原刺激によるシグナル伝達と $\mathrm{TCR} /$ 共刺激による細胞間接着部位への脂質ラフトの集合を抑 える。ガレクチンー1はガングリオシドGM 1 (55)か糖タンパク 質の糖鎖に結合する。しかしガレクチンー1リガンドについて はまだ評価されていない。

脂質ラフトに会合しているレクチン様分子についてVIP36 (56,57),アネキシンII,V,VI(58-62)、ZG16p(18)など報告がいくつ かある。しかしこれらの分子のラフトを介するシグナル伝達に おける役割については研究が進んでいない。

\section{D．脂質ラフトの不均一性}

脂質ラフトには、その組成、分布、機能の不均一性が知ら れている。密度勾配遠心において界面活性剤不溶性膜が光を散 乱する二本のバンドとして分離できることがある。それらの組 成は明らかに異なる。ブタ肺膜においては、両方のバンドとも SM、コレステロール、GPIアンカータンパク質に富んでいる。 しかしガラクトシルセラミドは低密度側のバンドのみで富み、 アネキシンII、VI、IP3レセプターは高密度側のバンドのみで富 んでいる(63)。マウス小脳においてはGSLは低密度側のバンド で富んでいる(64)。

メラノーマにおいては、界面活性剤不溶性画分を免疫沈降 でさらに二つの画分に分けられる。抗GM 3 抗体で分離したGM 3 に富む画分はSM、コレステロール、c-srcは含むがカベオリン は含まない。一方、抗カべオリン抗体で分離したカベオリンに 富む画分はグルコシルセラミド、rasと大量のコレステロールを 含んでいる $(65)$ 。

後根神経節ニューロンにおいても免疫沈降で二つの画分に 分けられる。GPIアンカープリオンタンパク質は主に細胞体に 
in detergent. Thy-1, abundantly expressed in neurites, was highly resistant to detergent solubilization (66). Distribution of SM and ganglioside recognized by A2B5 antibody is different in a multipolar oligodendrocyte progenitor cell. Although SM is present around the surface of the cell body, distribution of the ganglioside spreads from cell body to processes (67). Thus, functionally different proteins are organized in rafts of different lipid compositions.

\section{E. Perspective}

A number of studies have examined the role of lipids in physical properties and signaling of rafts. In contrast, the role of glycoconjugates remains to be explored. However, it can probably be revealed by gene targeting (68). In GalCer synthasedeficient mice, proteolipid protein, a raft protein of myelin, does not associate with lipid rafts (69) and functional breakdown of the lipid bilayer of the myelin membrane is observed $(70,71)$. Perturbation of lipid rafts in acid sphingomyelinase-deficient mice reduces tyrosine phosphorylation and consequently mitogenic signaling and increases susceptibility to apoptosis after TCR stimulation. The mice accumulate SM and GSLs (72). Furthermore, GlcCer synthase-deficient mice are embryoniclethal (73). GD2 synthase-deficient mice exhibit male sterility (74), age-related axonal degeneration (75) and attenuation of interleukin 2 signaling in spleen cells (76). GD2 synthase/ GD3 synthase double knockout mice exhibit lethal audiogenic seizures (77). GPI-anchor biosynthesis deficient mice are embryonic-lethal and keratinocyte-specific GPI-deficient mice exhibit abnormal skin development (78). These phenotypes are possibly due to dysfunction of lipid rafts.

\section{Acknowledgment}

This work was supported by Grants-in-Aid 11121237 for Scientific Research on Priority Area, and Special Coordination Funds of the Ministry of Education, Culture, Sports, Science and Technology,the Japanese Government.
分布し、界面活性剂に比較的可溶性である。GPIアンカータンパ ク質Thy-1は神経突起に豊富に発現し界面活性剂に高度に不溶性 である(66)。多突起型オリゴデンドロサイト前駆細胞において は、SMとA2B5抗体で認識されるガングリオシドとは分布が異 なる。SMは細胞体表面に存在するが、ガングリオシドは細胞体 から神経突起まで分布している(67)。このように機能の異なる夕 ンパク質が脂質組成の異なるラフトに組み込まれている。

\section{E. 展望}

ラフトの物理的性質、シグナル伝達における脂質の役割に ついては多くの研究がある。一方、複合糖質の役割については 研究が進んでいない。しかし、ジーンターゲッティングによる 結果がそれを明らかにするであろう(68)。ガラクトシルセラミド 合成酵素欠損マウスでは、ミエリンのラフトタンパク質である プロテオリピッドタンパク質は脂質ラフトと会合せず(69)、ミエ リン膜の機能に異常をきたしている(70,71)。酸性スフィンゴミ エリナーゼ欠損マウスでは、SMおよびGSLsが蓄積し脂質ラフ トが乱され、TCR刺激によるチロシンリン酸化と分裂シグナル が抑えられ、アポトーシスに対する感受性が増加する(72)。さら にグルコシルセラミド合成酵素欠損マウスは胎児期致死の表現 型を示す(73)。ガングリオシドGD 2 合成酵素欠損マウスでは、 精子形成不全(74)、加齢にともなう軸索変性(75)、ひ臓細胞にお けるインターロイキン 2 シグナルの減少が見られる(76)。ガング リオシドGD 2 合成酵素 /GD 3 合成酵素欠損マウスは、音刺激 で症攣をおこし死にいたる(77)。GPIアンカー合成酵素欠損マウ スは胎児期致死で、皮膚特異的GPIアンカー合成酵素欠損マウス では、皮虐の発生に異常をきたす(78)。これらの表現型が出る原 因は脂質ラフトの機能障害である可能性がある。

\section{謝 辞}

この仕事は、文部科学省の特定領域研究（11121237）およ び平成 12 年度科学技術振興調整費による「生体膜脂質の新し い機能の解析技術と制御技術の開発に関する研究」の一環とし て行われました。 
Trends in Glycoscience and Glycotechnology Vol.13 No.71 (May 2001) pp.251-259

\section{References}

1. Simons, K., and Toomre, D. (2000) Nature Rev. Mol.Cell Biol. 1, 31-39

2. Kurzchalia, T.V., and Parton, R.G. (1999) Curr. Opin. Cell Biol. 11, 424-431

3. Anderson, R.G.W. (1998) Annu. Rev. Biochem. 67, 199-225

4. Smart, E.J, Graf, G.A., McNiven, M.A., Sessa, W.C., Wngelman, J.A., Scherer, P.E., Okamoto, T., and Lisanti, M. (1999) Mol. Cell Biol. 19, 7289-7304

5. Masserini, M., Palestini, P., and Pitto, M. (1999) J. Neurochem. 73, 1-11

6. London, E., and Brown, D.A. (2000) Biochim. Biophys. Acta 1508, 182-195

7. Ohta, K., Sato, C., Matsuda, T., Toriyama, M., Lennarz WJ., and Kitajima, K. (1999) Biochem. Biophys. Res. Commun. 258, 616623

8. Ohta, K., Sato, C., Matsuda, T., Toriyama, M., Vacquie,r V.D., Lennarz, W.J. and Kitajima, K. (2000) Glycoconj. J. 17, 205-214

9. Rietveld, A., Neutz, S., Simons, K., and Eaton, S. (1999) J. Biol. Chem. 274, 12049-12054

10. Scheel, J., Srinivasan, J., Honnert, U., Henske, A., and Kurzchalia, T.V. (1999) Nature Cell Biol.1, 127-129

11. Kübler, E., Dohlman, H.G., and Lisanti, M. (1996) J. Biol. Chem. 271, 32975-32980

12. Xiao, Z., and Devreotes, P.N. (1997) Mol. Biol. Cell 8, 855-869

13. Nolan, D.P., Jackson, D.G., Biggs, M.J., Brabazon, E.D., Pays, A., Van Laethem, F., Paturiaux-Hanocq, F., Elliot, J.F., Voorheis, H.P., and Pays, E. (2000) J. Biol. Chem. 275, 4072-4080

14. Zhang, X., and Thompson, G.A.Jr. (1997) Biochem. J. 323, 197-206

15. Hanada, K., Nishijima, M., Akamatsu, Y., and Pagano, R.E. (1995) J. Biol. Chem. 270, 6254-6260

16. Merrill, A.H., Liotta, D.C., and Riley, R.T. (1996) Trends Cell Biol. 6, 218-223

17. Futerman, A.H. (1995) Trends Cell Biol. 5, 377-380

18. Schmidt, K., Schrader, M., Kern, H-F., and Kleene, R. (2001) J. Biol. Chem. 276, 14315-14323

19. Radin, N.S., Shayman, J.A., and Inokuchi, J. (1993) Adv.Lipid Res. 26, 183-213

20. Sheets, E.D., Lee, G.M., Simson, R., and Jacobson, K. (1997) Biochemistry 36, 12449-12458

21. Inokuchi J, Uemura S, Kabayama, K., and Igarashi Y (2000) Glycoconj. J. 17, 239-245

22. Zhang Y, Iwabuchi K, Nunomura S., and Hakomori S (2000) Biochemistry 39, 2459-2468

23. Simons, M., Friedrichson, T., Schulz, J.B., Pitto, M., Masserini, M., and Kurzchalia, T.V. (1999) Mol.Biol.Cell 10, $3187-3196$

24. Ostermeyer, A.G., Beckrich, B.T., Ivarson, K.A., Grove, K.E., and Brown, D.A. (1999) J. Biol. Chem. 274, 34459-34466

25. Kasahara, K., Watanabe, K., Takeuchi, K., Kaneko, H., Oohira, A., Yamamoto, T., and Sanai, Y. (2000) J. Biol. Chem. 275, 3470134709

26. Kasahara, K., Watanabe, Y., Yamamoto, T., and Sanai, Y. (1997) J. Biol. Chem. 272, 29947-29953

27. Kasahara, K., and Sanai, Y. (1999)Biophys. Chem. 82, 121-127

28. Kasahara, K., and Sanai, Y. (2000) Glycoconj. J. 17, 153-162

29. Hakomori, S., Handa, K., Iwabuchi, K., Yamamura, S., and Prinetti, A. (1998) Glycobiology 8(10), xi-xix

30. Iwabuchi, K., Zhang, Y., Handa, K., Withers, D.A., Sinay, P., and Hakomori, S. (2000) J. Biol. Chem. 275, 15174-15181

31. Matsuura, K., Kitakouji, H., Sawada, N., Ishida, H., Kiso, M, Kitajima. K., and Kobayashi, K. (2000) J. Am. Chem. Soc. 122, 74067407

32. Hashimoto, Y., Suzuki, M., Crocker, P.R., and Suzuki, A. (1998) J. Biochem.123, 468-478

33. Hashizume, M., Sato, T., and Okahata, Y. (1998) Chem. Lett. 399-400

34. Krämer, E., Klein, C., Koch, T., Boytinck, M., and Trotter, J. (1999) J. Biol. Chem. 274, 29042-29049

35. Ilangumaran, S., He, H.-T., and Hoessli, D.C. (2000) Immunol. Today 21, 2-6

36. Sheets, E.D., Holowka, D., and Baird, B. (1999) Curr. Opin. Chem. Biol. 3, 95-99

37. Viola, A., Schroeder, S., Sakakibara, Y., and Lanzavecchia, A. (1999) Science 283, 680-682

38. Field, K.A., Apgar, J.R., Hong-Geller, E., Siraganian, R.P., Baird, B., and Holowka, D. (2000) Mol. Biol. Cell 11, $3661-3673$

39. Marshall, CJ. (1995) Cell 80, 179-185

40. Peiro, S., Comella, J.X., Enrich, C., Nartin-Zanca, D., and Rocamora, N. (2000) J. Biol. Chem. 275, 37846-37852

41. Mutoh, T., Tokuda, A., Miyadai, T., Hamaguchi, M., and Fujiki, N. (1995) Proc. Natl. Acad. Sci. USA 92, 5087-5091

42. Mutoh, T., Tokuda, A., Inokuchi, J., and Kuriyama, M. (1998) J. Biol. Chem. 273, 26001-26007

43. Fukumoto, S., Mutoh, T., Hasegawa, T., Miyazaki, H., Okada, M., Goto, G., Furukawa, K., Urano, T., and Furukawa, K. (2000) J. Biol. Chem. 275, 5832-5838

44. Mutoh, T., Hamano, T., Tkuda, A., and Kuriyama, M. (2000) Glycoconj. J. 17, 233-237

45. Bremer, E.G., Schlessinger, J., and Hakomori, S. (1986) J. Biol. Chem. 261, 2434-2440

46. Meuillet, E.J., Kroes, R., Tamamoto, H., Warner, T.G., Ferrari, J., Mania-Farnell, B., George, D., Rebbaa, A., Moskal, J.R., and Bremer, E.G. (1999) Cancer Res. 59 234-240

47. Meuillet, E.J., Mania-Farnell, B., George, D., Inokuchi, J., and Bremer, E.G. (2000) Exp. Cell Res. 256, 74-82

48. Waugh MG, Lawson D., and Hsuan JJ (1999) Biochem. J. 337, 591-597

49. Zhou, Q., Hakomori, S., Kitamura, K., and Igarashi, Y. (1994) J. Biol. Chem. 269, 1959-1965

50. Kukimoto, M., Nureki, O., Shirouzu, M., Katada, T., Hirabayashi, Y., Sugiya, H., Furuyama, S., Yokoyama, S., and HaraYokoyama, M. (2000) J. Biochem. 127, 181-184

51. Hara-Yokoyama, M., Nagatsuka, Y., Katsumata, O., Irie, F., Kontani, K., Hoshino, S., Katada, T., Ono, Y., Fujita-Yoshigaki, J., Furuyama, S., and Hirabayashi, Y. Biochemistry (in press)

52. Murakami, M., Kambe, T., Shimbara, S., Yamamoto, S., Kuwata, H., and Kudo, I. (1999) J. Biol. Chem. 274, 29927-29936

53. Milev, P., Maurel P., Häring, M., Margolis, R.K., and Margolis, R.U. (1996) J. Biol. Chem. 271, 15716-15723

54. Chung, C.D, Patel, V.P, Moran, M., Lewis, L.A., and Miceli, M.C. (2000) J.Immunol. 165, 3722-3729

55. Kopitz, J., von Reitzenstein, C., Burchert, M., Cantz, M., and Gabius, H.-J. (1998) J. Biol. Chem. 273, 11205-11211

56. Fiedler, K., Parton, R.G., Kellner, R., Etzold ,T., and Simons, K. (1994) EMBO J. 13 1729-1740 
57. Hara-Kuge, S., Ohkura, T., Seko, A., and Yamashita, K. (1999) Glycobiology 9, 833-839

58. Harder, T., and Gerke, V. (1994) Biochem. Biophys. Acta 1223, 375-382

59. Babiychuk, E.B., and Draeger, A. (2000) J. Cell Biol. 150, 1113-1123

60. Kassam, G., Manro, A., Braat, C.E., Louie, P., Fitzpatrick, S.L., and Waisman, D.M. (1997) J. Biol. Chem. 272, $15093-15100$

61. Ishitsuka, R., Kojima, K., Utsumi, H., Ogawa, H., and Matsumoto, I. (1998) J. Biol. Chem. 273, $9935-9941$

62. Gao-UoZumi, C.X., Uozumi, N., Miyoshi, E., Nagai, K., Ikeda, Y., Teshima, T., Noda, K., Shiba, T., Honke, K., and Taniguchi, N. (2000) Glycobiology 10, 1209-1216

63. Parkin, E.T., Turner, A.J., and Hooper, N.M. (1996) Biochem. J. 319 887-896

64. Olive, S., Dubois, C., Schachner, M., and Rougon, G. (1995) J. Neurochem. 65, 2307-2317

65. Iwabuchi, K., Handa, K., and Hakomori, S. (1998) J. Biol. Chem. 273, 33766-33773

66. Madore, N., Smith, K.L., Graham, C.H., Jen, A., Brady, K., Hall, S., and Morris, R. (1999) EMBO J. 18, 6917-6926

67. Nakai, Y., Sakurai, Y., Yamaji, A., Asou, H., Umeda, M., Uyemura, K., and Itoh, K. (2000) J.Neurosci.Res. 62, 521-529

68. Muramatsu, T. (2000) J.Biochem. 127, 171-176

69. Simons, M., Krämer, E., Thiele, C., Stoffel, W., and Trotter, J. (2000) J. Cell Biol. 151, 143-153

70. Coetzee, T., Fujita, N., Dupree, J., Shi, R., Blight, A., Suzuki, K. Suzuki, K., and Popko, B. (1996) Cell 86, 209-219

71. Bosio, A., Binczek, E., and Stoffel, W. (1996) Proc. Natl. Acad. Sci. USA, 93, 13280-13285

72. Nix, M., and Stoffel, W. (2000) Cell Death Differentiation 7 413-424

73. Yamashita, T. Wada,R., Sasaki, T., Deng, C., Bierfreund, U., Sandhoff, K., and Proia, R.L. (1999) Proc. Natl. Acad. Sci. USA 96, 9142-9147

74. Takamiya, K., Yamamoto, A., Furukawa, K., Zhao, J., Fukumoto, S., Yamashiro, S., Okada, M., Haraguchi, M., Shin, M., Kishikawa M, Shiku, H., Aizawa, S., and Furukawa, K. (1998) Proc. Natl. Acad. Sci. USA 95, 12147-12152

75. Sheikh, K.A., Sun, J., Liu, Y., Kawai, H., Crawford, T.O., Proia, R.L., Griffin, J.W., and Schnaar, R.L. (1999) Proc. Natl. Acad. Sci. USA 96, 7532-7537

76. Zhao, J., Furukawa, K., Fukumoto, S., Okada, M., Furugen, R., Haraguchi, M., Miyazaki, H., Takamiya, K., Aizawa, S., Shiku, H., Matsuyama, T., and Furukawa, K. (1999) J. Biol. Chem. 274, 13744-13747

77. Kawai, H., Allende, M.L., Wada, R., Kono, M., Sango, K., Deng, C., Miyakawa, T., Crowley, J.N., Werth, N., Bierfreund, U., Sandhoff K., and Proia, R.L.(2001) J. Biol. Chem. 276, 6885-6888

78. Tarutani, M., Itami, S., Okabe, M., Ikawa, M., Tezuka, T., Yoshikawa, K., Kinoshita T., and Takeda, J. (1997) Proc. Natl. Acad. Sci. 94, 7400-7405

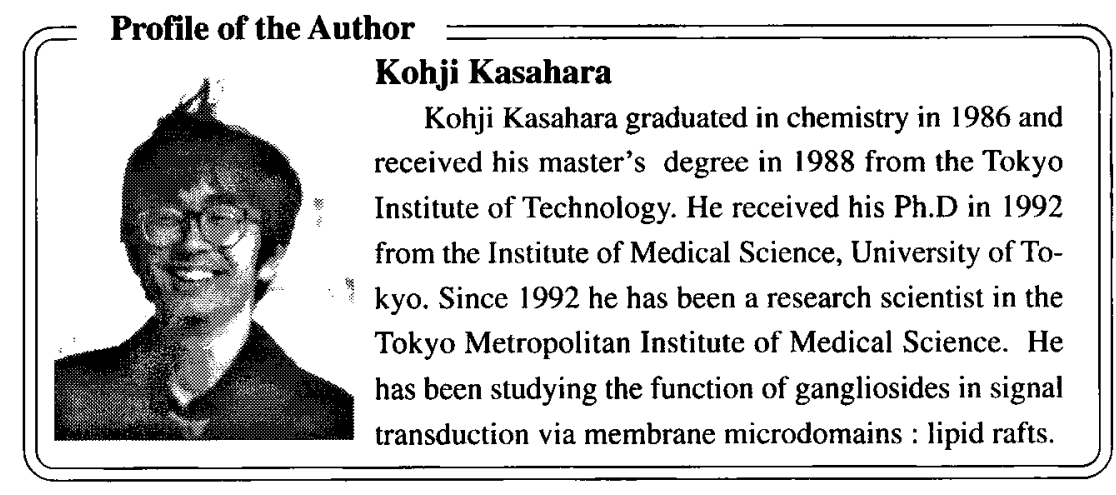

